the shadow cone above sea-level will be $30 \mathrm{~km}$. (I9

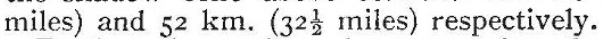

Further, he makes the suggestion that although totality may not yet occur, the corona may be seen, for at previous eclipses it has been seen well before and after totality, and in Igoo was photographed by Mr. Willis eight minutes after.

Finally, he presents the peculiar possibility of there being neither an annular nor a total eclipse; this would occur if the mean apparent diameter of the moon were just insufficient to produce totality, because of the depressions at the limb, yet was so great that the mountains at the moon's limb projected far enough to break up the continuity of the solar limb.

In No. 4562 of the Astronomische Nachrichten Dr. Graff also discusses the position of the lunar mountains, and also the possible observations of the lowest levels of the chromosphere. He suggests, finally, that suitably arranged astrophysical observations may not prove so unprofitable as it has been generally supposed they must be in the circumstances of the coming eclipse.

Nova Geminorum No. 2.-A number of messages concerning observations of Herr Enebo's new star have been received by the Kiel Centralstelle, and are published in No. $45^{62}$ of the Astronomische Nachrichten.

At Christiania, early on March I3, Prof. Schroeter estimated the magnitude as $4 \cdot 0$, while Dr. Hartwig at Bamberg on March I3, at Ioh. $23.9 \mathrm{~m}$. (Bamberg M.T.), found it to be 4.3 ; he gives the colour as reddish, and the position, for $19 \mathrm{I} 2 \cdot 0$, as $6 \mathrm{~h} .49 \mathrm{~m}$. I $x \cdot 87 \mathrm{~s} .,+32^{\circ}$ I $5^{\prime} 6^{\prime \prime}$.

On March I4 Prof. Pickering reported that the spectrum of the nova was of the $F_{5}$ type, but on March I5 he reported a change to a bright-line spectrum. In the Harvard classification the type $\mathrm{F}_{5} \mathrm{G}$ represents spectra similar to that of Procyon, the Procyonian type in the South Kensington classification, which is the next earlier type to the solar stars.

According to Dr. Hartwig, the nova corresponds very closely with a thirteenth-magnitude star on the Palisa-Wolf charts. An observation made at II.45 p.m. on March 20 showed the magnitude of the nova to be about $5 \cdot 4$.

Analyses of Stone Meteorites.-A valuable contribution to the study of meteorites appears in Publication I5I of the Field Museum of Natural History, where Mr. O. C. Farrington publishes a list of analyses of 125 stone meteorites, and a scheme of classification. An " average" composition, derived from the whole, gives the following substances, and their percentages, as the principal constituents:$\mathrm{SiO}_{2}\left(39^{\circ} 12\right), \mathrm{Al}_{2} \mathrm{O}_{3}\left(2^{\circ} 62\right)$, FeO (16.13), $\mathrm{MgO}\left(22^{\circ} 42\right)$,

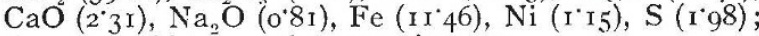
there are thirteen other constituents.

It is worth noting that this list does not truly represent the relative spectroscopic importance of the various substances in meteorites. In the "Spectroscopic Comparison of Metals present in Certain Terrestrial and Celestial Light Sources," published from the Solar Physics Observatory in 1907, the chief metals were arranged in order of the prominence of their strongest lines in the spectra of the eight or nine stony meteorites examined. The order was as follows :- $\mathrm{Cr}, \mathrm{Na}, \mathrm{Al}, \mathrm{Mg}, \mathrm{Mn}, \mathrm{Si}, \mathrm{Ca}, \mathrm{Fe}$, $\mathrm{Ti}, \mathrm{V}, \mathrm{K}, \mathrm{Sr}, \mathrm{Ni}$, and $\mathrm{Ba}$.

In the spectra of all the certain meteorites, chromium is very well marked, yet in the chemical analysis given by $\mathrm{Mr}$. Farrington it is only represented by $0_{4} 4 \mathrm{I}$ per cent. of $\mathrm{Cr}_{2} \mathrm{O}_{3}$.

Observations of Novæ.-Observations of the magnitude of Nova Lacertæ are published by Prof.
Nijland in No. 4562 of the Astronomische Nachrichten. Between January I and December I5, I9II, the magnitude sank from $7 \cdot 5^{\circ}$ to $1 \mathrm{I} \cdot 40$, and the plotted values show practically no oscillations of the brightness.

Observations of the suspected Nova 87. I9I I Persei, discovered by Mr. D'Esterre, are reported by that observer in the same journal. The later photographs, showing fourteenth-magnitude stars, show, in the position of the nova, a nebulous patch in which appear to be involved three condensations or very faint nebulous stars.

\section{LIFE IN THE OCEAN.'}

M ORE than twenty years have passed away since $\mathrm{W}$ the veteran physiologist of $\mathrm{Kiel}-\mathrm{Victor} \mathrm{Hen}$ sen-initiated a new era in plankton research characterised by the application of biometrical methods. $\mathrm{His}$ inventions and investigations culminated in the equipment of an oceanic expedition which was to be an experiment on a large scale. It was one of the first German scientific expeditions, and certainly the first oceanic expedition to be devoted entirely to the study of the floating organisms.

Hensen's pioneer work, with its enormous labour and brilliant negotiation of abstruse problems, was carried out in the face of much unfair criticism-the famous polemic of Haeckel, "Plankton Studien," will long be remembered by the Kiel school.

During the years that have elapsed since, the same kind of destructive criticism has been at times proclaimed, and almost always by those who seem to have taken no trouble to study the work they would demolish.

The material collected by this "plankton" expedition has been examined by specialists, and now, after twenty-two years, Hensen has taken up the pen and written what should be the final volume (I), the last word, were it not that two or three reports still remain unfinished.

The greater part of the volume deals with the quantitative greographical distribution of pelagic organisms in the North Atlantic. Numerous tables are appended, and these, with the reports, complete what must be considered the first scientific attempt to determine the distribution of the plankton of the high seas. The work as a record is of great value. It must be remembered, however, that the studies of recent years have emphasised the rema-lable seasonal variations occurring in the plankton of both lakes and seas; hence, the observations of the IIumboldt-Stiftung expedition, which lasted but three and a half months, must be regarded as only presenting a phase in the distribution of life in the ocean.

Perhaps the most interesting part of the volume is Hensen's résumé, which deals with contemporaneous plankton work and other problems which have been much discussed during the past few years, such as Putter's theory and the theories of de Vries.

The great aim of the plankton expedition was the determination of the actual number of the different organisms in the waters of the high seas. Within certain limits this has been carried out, but on the whole the figures looked at in this light are of little importance. It is the methodical manner in which quantitative nets are used, and the elimination of

1 (r) "Das Lehen in Ozean nach Zählungen seiner Bewohner : Uebersicht und Resultate der quantitativen Untersuchungen." Bv Prot. V. Hensen. (Ergebnisse der Plankton-Expedition der Humholdt.Stiftung. Bd. v. O.) Pp. v+406+Tabellen (pp. $8+x x v i n i$ tables +map.) (Kiel and Leipzig:

(2) "Ueber das Nannoplankton und die Zentrifugierung , kleinster Wasserproben zur Gewinnung desselben in lebenden Zustande." By H.

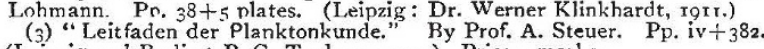
(Leipzig and Berlin: B. G. Teubner, 1911.) Price 7 marks. 
the personal equation by the enumeration of the organisms, that makes biological work of this kind so valuable. Whatever errors creep into quantitative plankton studies-and no one knows better than the planktologist the inaccuracy of the methods--they occur in a similar way throughout, and affect all calculations to the same extent. The final result is a series of comparable observations, and the possibility of comparison is the keynote of quantitative plankton work.

Hensen's treatment of two of his critics does not seem quite fair. Kofoid's objection that the original net lost many of the smallest organisms has been upheld by the work of Lohmann. As for Herdman's work in the Irish Sea, the absence (which he has insisted on) of the uniform distribution of plankton necessary if observations made at stations far apart are to be of any value cannot be denied. Furthermore, it is just in waters like the North Sea and Irish Sea that most naturalists find it possible to work. Whatever may be the cause of the complexities in the Irish Sea, the variations which have been followed by the Port Erin workers have been of such magnitude that no small errors could invalidate the deductions drawn.

The influence of Hensen and his quantitative methods has been greater than at first sight would be imagined. There is no doubt that, as in many other cases, work along quite different lines has been stimulated or even created. Take, for example, the careful analyses of sea water, the study of the distribution of nitrogen, of silica, and hydrographic work in general. There was a continuous demand for very accurate knowledge from those who would explain distribution by the altered environment. It was the plankton expedition itself that startled biologists with the statement that life was more abundant in the Arctic and temperate waters than in the tropics, and out of this has arisen the ingenious attempts to explain the anomaly. Bound up with this is the search for the factors which govern the seasonal changes in the plankton and the detailed researches which have been made on the latter in seas and lakes throughout the world. The question of the food supply of aquatic organisms, now no longer a simple subject, but one bristling with unsolved problems, requires further research along many different lines, particularly chemical and physiological.

Finally, the systematist who follows the indiridual organisms, counting as they pass across the field of view, recognises the variations in shape and size, and hesitates before coining new species (especially if working through a year's catches). In fact, for the study of evolution we need to go to the simplest organisms existing under the most simple conditions of environment. For this purpose there is a wide field open for research in the plankton of warm waters. Hensen shows that the seasonal variations, which complicate so much plankton studies in our waters, are to a great extent absent in the tropics. It is probably the seasonal variations which are at the bottom of many strange features of distribution round our islands. It would be quite impossible to touch on the numerous points of interest (many of which should create discussion) in a short article. Victor Hensen must be congratulated upon the conclusion of a work to which he has given so much of an active life.

(2) Two other works which have recently been published may very conveniently be discussed here. The first deals entirely with those small organisms which pass through the finest tissue of which plankton nets are made.

Iohmann has proved himself to be one of the foreNO. 22 I3, VOL. 89$]$ most plankton workers in the world, and it is to this man of science that we owe our knowledge of the limitations of Hensen's methods. Thus the methods of the Kiel school have received their critical tests at the hands of the Kiel school. Lohmann proposes to use the term "nannoplankton" for the very small organisms, both animal and vegetable, of the pelagic world.

At the present time Schütt's terms, macro-, meso-, and mikro-plankton, are usually employed. No exact definitions of these groups were ever given, but the macroplankton was understood to include such organisms as medusæ, whilst the rest of the plankton in a net catch belonged to the groups, meso- and mikroplankton. The former of these two divisions included the copepoda, worms, \&c., and the protozoa and protophyta made up the second. To these three terms Lohmann adds two others: the "megaloplankton," for all large organisms visible from a ship's deck and varying in size from centimetres to metres, and the nannoplankton for the most minute forms.

Naturally, different apparatus is required for the collection of the nannoplankton, and the net has been supplanted by the centrifuge. Water can be bottled at any depth, and it has been found that quite small quantities suffice.

It must be remembered that though the actual volume of the nannoplankton is small, the degree of importance depends on the rapidity of multiplication and the duration of life of the organisms of this group, and in this respect their absence from the net catches of the plankton expedition is much to be deplored.

(3) The other work to be mentioned differs entirely from the above in being a text-book, and there can be no doubt whatever that such a book is necessary to-day in consequence of the great extension of plankton work during the last few years. This volume gives a detailed and fair description of all the methods emploved, with the results of recent researches in seas, lakes, and rivers.

Its greatest value will be perhaps to those biologists and general scientific workers who wish to obtain information about this branch of biological science without wading through the vast number of small napers which have been already published. Prof. Steuer is to be congratulated on the very able way he has brought so many different lines of work together, and the volume ought to find a place waiting for it in most university libraries.

W. J. DAKIN.

\section{UNIVERSITY REFORM IN NEW ZEALAND.}

IT may be taken for granted that all universities are not built on the same pattern; that local conditions and the requirements of the population have to be taken into consideration. The American and German universities, with their plans of government and conditions of study, meet the requirements of the respective peoples; Oxford and Cambridge, with features in common with one another, differ widely from the rest of the British universities in many respects. The type of the Scotch universities is unlike that of the modern English institutions, such as Liverpool and Manchester, while that of London is organised in a fashion peculiar to itself.

It is not to be wondered at, therefore, that the University of New Zealand should present anomalies in its constitution; the peculiarly isolated position of the country, the great difficulties of communication between its chief towns, especially in early days; the paucity of university men both on the staffs of the colleges and outside their walls at the period of its foundation: the local prejudices, amounting almost to 